\title{
CAPITAL ADEQUACY RATIO, LOAN DEPOSIT RATIO DAN NON PERFORMING LOAN TERHADAP PROFITABILITAS
}

\author{
Alfian Agus Putranto \\ alfianputranto05@gmail.com \\ Farida Titik Kristanti \\ Dewa Putra Khrisna Mahardika \\ Fakultas Ekonomi dan Bisnis, Universitas Telkom
}

\begin{abstract}
ROA is used to measure the ability of the bank's management in obtaining the overall profit of the total assets owned. This study aims to examine the influence of Capital Adequacy Ratio (CAR), Loan Deposit Ratio (LDR) and Non Performing Loan (NPL). Profitability is proxied by Return on Assets (ROA) in Commercial Bank listed on Indonesia Stock Exchange (BEI) in the period of 2011-2015. The population in this study are the commercial bank listed on the Stock Exchange. Sample selection technique used is purposive sampling and acquired 31 commercial banks with the 2011-2015 study period. Methods of data analysis is panel data regression analysis. The results showed that simultaneous Capital Adequacy Ratio (CAR), Loan Deposit Ratio (LDR) and Non Performing Loan (NPL) have a significant effect on profitability. While partially, Capital Adequacy Ratio (CAR) significant positive effect, Non Performing Loan (NPL) significant negative effect, while Loan Deposit Ratio (LDR) has no effect on profitability.
\end{abstract}

Keywords : capital adequacy ratio, loan deposit ratio, non performing loan, return on assets

\begin{abstract}
Abstrak
ROA digunakan untuk mengukur kemampuan manajemen bank dalam memperoleh laba secara keseluruhan dari total aktiva yang dimiliki. Penelitian ini bertujuan untuk menguji pengaruh Capital Adequacy Ratio (CAR), Loan Deposit Ratio (LDR) dan Non Performing Loan (NPL). terhadap profitabilitas yang diproksikan dengan Return on Asset (ROA) pada Bank Umum yang terdapat pada Bursa Efek Indonesia (BEI) periode 2011-2015. Data yang digunakan dalam penelitian ini diperoleh dari data laporan keuangan. Populasi dalam penelitian ini adalah Bank Umum yang terdaftar pada BEI dengan purposive sampling diperoleh 31 Bank Umum dengan periode penelitian pada tahun 2011-2015. Metode analisis data dalam penelitian ini adalah analisis regresi data panel. Hasil penelitian menunjukkan bahwa secara simultan CAR, LDR dan NPL berpengaruh signifikan terhadap ROA. Sedangkan secara parsial, CAR berpengaruh positif, NPL berpengaruh negatif, sedangkan LDR tidak berpengaruh terhadap ROA.
\end{abstract}

Kata Kunci : capital adequacy ratio, loan deposit ratio, non performing loan, return on assets 


\section{PENDAHULUAN}

Salah satu ukuran kinerja perusahaan adalah tingkat keuntungan atau laba. Laporan mengenai rugi laba suatu perusahaan, termasuk perbankan, merupakan hal yang sangat penting dalam laporan tahunan. Salah satu teknik dalam analisis laporan keuangan adalah analisis rasio keuangan. Profitabilitas merupakan indikator yang paling penting untuk mengukur kinerja suatu bank. Return On Assets (ROA) memfokuskan kemampuan perusahaan untuk memperoleh earning dalam kegiatan operasi perusahaan dengan memanfaatkan aktiva yang dimilikinya. Sehingga dalam penelitian ini ROA digunakan sebagai ukuran kinerja perbankan. ROA penting bagi bank karena ROA digunakan untuk mengukur efektivitas perusahaan di dalam menghasilkan keuntungan dengan memanfaatkan aktiva yang dimilikinya. Selama lima tahun terakhir ROA bank umum cenderung turun namun Aset bank umum selalu meningkat sehingga menandakan ketidakefektifan dalam mengelola aset yang ada.

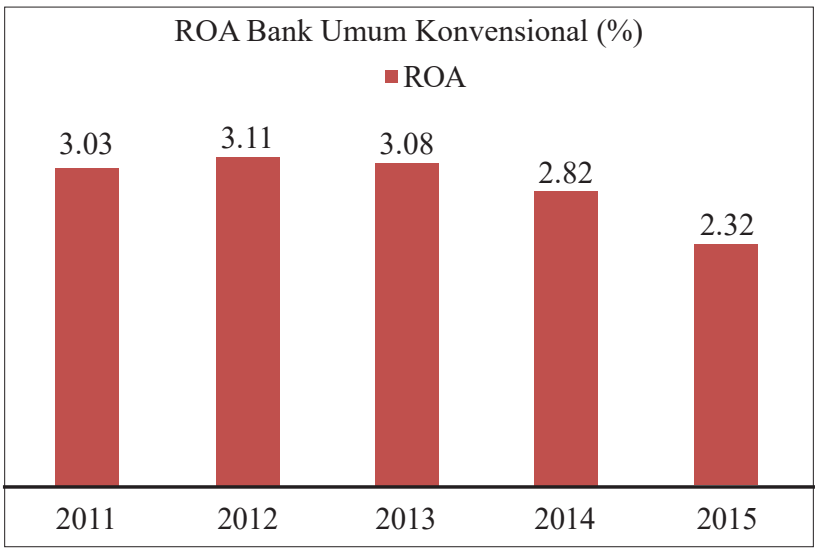

Sumber : Statistik Perbankan Indonesia

Gambar 1. Perkembangan Return on Assets perbankan

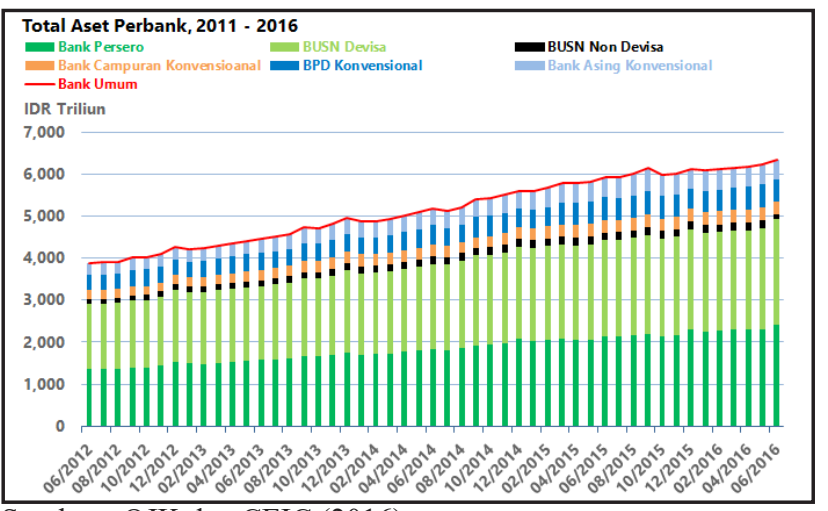

Sumber : OJK dan CEIC (2016)

Gambar 2. Perkembangan Total Aset Perbankan

Faktor yang diindikasi dapat mempengaruhi ROA yang akan digunakan dalam penelitian ini diantaranya yaitu CAR, LDR dan NPL. Pemilihan ketiga variabel ini dikarenakan terdapat perkembangan yang tidak searah selama lima tahun terakhir.

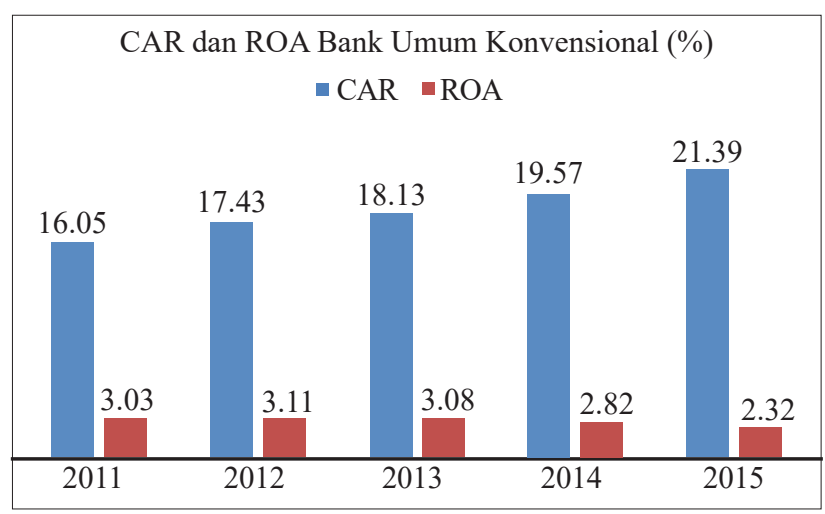

Sumber : Statistik Perbankan Indonesia

Gambar 3. Perkembangan Capital Adequacy Ratio perbankan

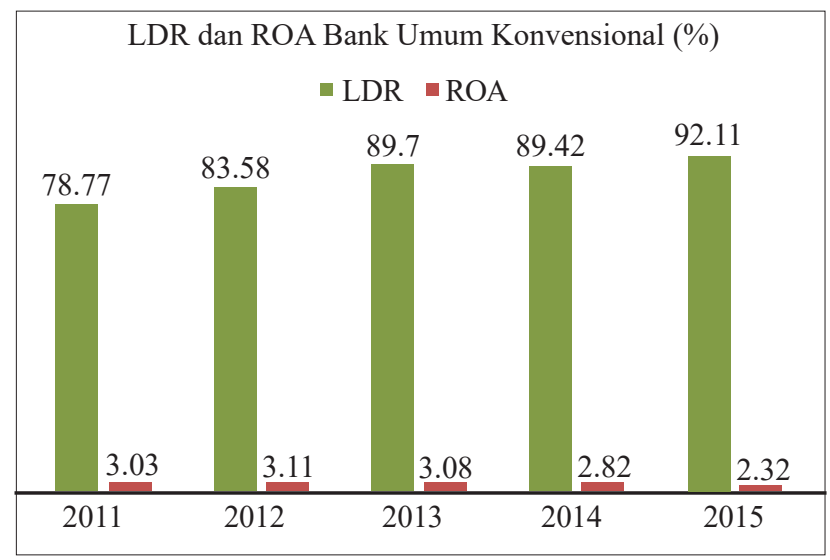

Sumber : Statistik Perbankan Indonesia

Gambar 4. Perkembangan Loan Deposit Ratio perbankan

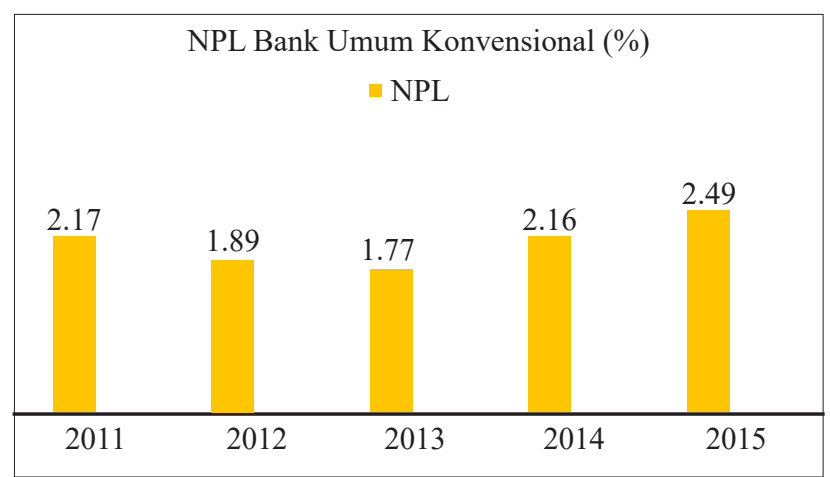

Sumber : Statistik Perbankan Indonesia

Gambar 5. Perkembangan Non Performing Loan perbankan

Dalam UU No.10/1998 Pasal 1 ayat 2 disebutkan bahwa bank ialah badan usaha yang menghimpun dana dari masyarakat dalam bentuk simpanan dan menyalurkannya kepada masyarakat dalam bentuk kredit dan/atau bentuk lainnya dalam rangka meningkatkan taraf hidup kebanyakan rakyat. Dalam buku Bank dan Lembaga Keuangan Lainnya, Kasmir (2012) mengatakan bahwa Bank Umum yaitu bank yang melaksanakan kegiatan usaha secara konvensional dan atau beradasrkan prinsip syariah yang dalam kegiatannya 
memberikan jasa dalam lalu lintas pembayaran. Sifat jasa yang diberikan adalah umum, dalam arti dapat memberikan seluruh jasa perbankan yang ada. Begitu pula dengan wilayah operasinya dapat dilakukan di seluruh wilayah. Bank umum sering disebut bank komersil.

Teori signaling menyatakan bahwa perusahaan yang berkualitas baik dengan sengaja akan memberikan sinyal pada pasar, dengan demikian pasar diharapkan dapat membedakan perusahaan yang berkualitas baik dan buruk agar sinyal tersebut baik maka harus dapat ditangkap pasar dan dipresepsikan baik serta tidak mudah ditiru oleh perusahaan yang memliki kualitas yang buruk (Meginson dalam Durrotun, 2012).

Return on Assets (ROA) merupakan rasio keuangan perusahaan yang berhubungan dengan profitabilitas mengukur kemampuan perusahaan menghasilkan keuntungan atau laba pada tingkat aset tertentu. Return On Asset (ROA) menurut Kasmir (2012:201) adalah rasio yang menunjukan hasil (return) atas jumlah aktiva yang digunakan dalam perusahaan. Selain itu, ROA memberikan ukuran yang lebih baik atas profitabilitas perusahaan karena menunjukan efektivitas manajemen dalam menggunakan aktiva untuk memperoleh pendapatan. Dengan mengetahui ROA, dapat menilai apakah perusahaan telah efisien dalam menggunakan aktivanya dalam kegiatan operasi untuk menghasilkan keuntungan.

$$
\mathrm{ROA}=\frac{\mathrm{EAT}}{\text { Total Asset }} \times 100 \%
$$

Menurut Wardiah (2013) CAR adalah rasio kecukupan modal bank atau kemampuan bank dalam permodalan yang ada untuk menutup kemungkinan kerugian dalam perkreditan atau perdagangan suratsurat berharga. Semakin tinggi CAR, maka akan semakin besar kemampuan bank dalam meminimalisir risiko kredit yang terjadi sehingga kredit bermasalah yang terjadi dalam bank akan semakin rendah. Formula yang ditentukan oleh Bank for International Settlement (BIS) atas CAR adalah rasio minimum $8 \%$ permodalan terhadap aktiva yang mengandung risiko.

$$
\mathrm{CAR}=\frac{\text { Modal }}{\mathrm{ATMR}} \times 100 \%
$$

Latumaerissa (2014:96) mengemukakan bahwa rasio LDR adalah rasio keuangan perusahaan perbankan yang berhubungan dengan aspek likuiditas. Rasio ini menggambarkan sejauh mana simpanan digunakan untuk pemberian pinjaman. Rasio LDR yang tinggi menunjukkan bahwa suatu bank memberikan pinjaman dengan seluruh dana yang dimiliki (loan up) atau relatif tidak likuid. Sebaliknya rasio yang rendah menunjukkan bank yang likuid dengan kelebihan kapasitas dana yang siap untuk dialirkan ke dalam aktivitas penyaluran kredit, pinjaman atau pemberian kredit. Loan Deposit Ratio merupakan perbandingan antara jumlah kredit yang disalurkan terhadap jumlah dana pihak ketiga yang dihimpun. Rasio likuiditas yang ditetapkan oleh Bank Indonesia berada di kisaran 78\%-100\%. Semakin tinggi rasio menunjukkan semakin riskan kondisi likuiditas bank, sebaliknya semakin rendah Loan to Deposit Ratio (LDR) menunjukkan kurangnya efektifitas bank dalam menyalurkan kredit sehingga hilangnya kesempatan bank untuk memperoleh laba.

$$
\mathrm{LDR}=\frac{\text { Total Kredit }}{\text { Dana Pihak Ketiga }} \times 100 \%
$$

Menurut Mahmoeddin (2010) kredit bermasalah adalah kredit di mana debiturnya tidak memenuhi persyaratan yang telah diperjanjikan sebelumnya, misalnya persyaratan mengenai pembayaran bunga, pengembalian pokok pinjaman, peningkatan margin deposit, pengikatan dan peningkatan angungan dan sebagainya. Kredit dianggap sebagai salah satu faktor yang sangat mempengaruhi pendapatan maupun beban bank, karena jika kredit berada pada batas wajar atau lancar kredit dapat menjadi sumber penerimaan yang efektif untuk bank, sebaliknya jika kredit berada pada level macet kredit dapat menjadi sumber kerugian bank. Dalam Peraturan Bank Indonesia No 17/11/PBI/2015 Tentang Perubahan Atas Peraturan Bank Indonesia No 15/15/PBI/2013 Tentang Giro Wajib Minimum Bank Umum Dalam Rupiah Dan Valuta Asing Bagi Bank Umum Konvensional bahwa tingkat rasio NPL tidak boleh lebih dari $5 \%$.

$$
\mathrm{NPL}=\frac{\text { Kredit Bermasalah }}{\text { Total Kredit }} \times 100 \%
$$

Capital Adequacy Ratio (CAR) menunjukkan seberapa besar jumlah seluruh aktiva bank yang mengandung risiko (kredit, penyertaan, surat berharga, dan tagihan pada bank lain) yang ikut dibiaya dari modal sendiri di samping memperoleh dana-dana dari sumber di luar bank. Semakin tinggi rasio CAR maka profitabilitas bank akan meningkat karena kerugian-kerugian yang ditanggung bank dapat diserap oleh modal yang dimiliki bank tersebut. CAR berpengaruh positif dan signifikan terhadap ROA sesuai dengan hasil penelitian Lyla Rahma (2011) dan Kunto Wibisono (2012).

Loan Deposit Ratio (LDR) merupakan rasio yang menunjukkan tingkat likuiditas bank. Semakin tinggi rasio tersebut memberi indikasi semakin tinggi juga kemampuan likuiditas bank yang bersangkutan. Oleh karena itu semakin tinggi tingkat likuiditas bank tersebut maka profitabilitas bank semakin meningkat. Loan Deposit Ratio berpengaruh positif signifikan terhadap profitabilitas bank sesuai dengan penelitian terdahulu yang dilakukan oleh Riski Agustiningrum (2012) dan Hardiyanti (2012). 
NPL ini sangat mempengaruhi kinerja bank terutama kualitas aset dan semakin besar risiko kredit yang ditanggung pihak bank yang berarti kinerja keuangan bank semakin menurun. Hal ini juga mengindikasikan menurunnya profitabilitas yang diraih oleh bank tersebut. menunjukan bawa Non Performing Loan berpengaruh negatif dan signifikan terhadap profitabilitas perbankan sesuai dengan hasil penelitian Hasil penelitian Lyla Rahma (2011) dan Riski Agustiningrum (2012).

\section{METODE}

Operasionalisasi variabel ditunjukkan pada Tabel 1.

Tabel 1. Operasionalisasi Variabel

\begin{tabular}{lcc}
\hline $\begin{array}{c}\text { Variabel dan Konsep } \\
\text { Variabel }\end{array}$ & Indikator & Skala \\
\hline CAR $\left(\mathrm{X}_{1}\right)$ adalah & & \\
perbandingan rasio & & Modal \\
tersebut antara rasio & $\mathrm{CAR}=\frac{\text { Aktiva }}{100 \%}$ & Rasio \\
modal terhadap Aktiva & Tertimbang & \\
Tertimbang Menurut & Menurut & \\
Resiko dan sesuai & Risiko & \\
ketentuan pemerintah & &
\end{tabular}

(Kasmir 2014).

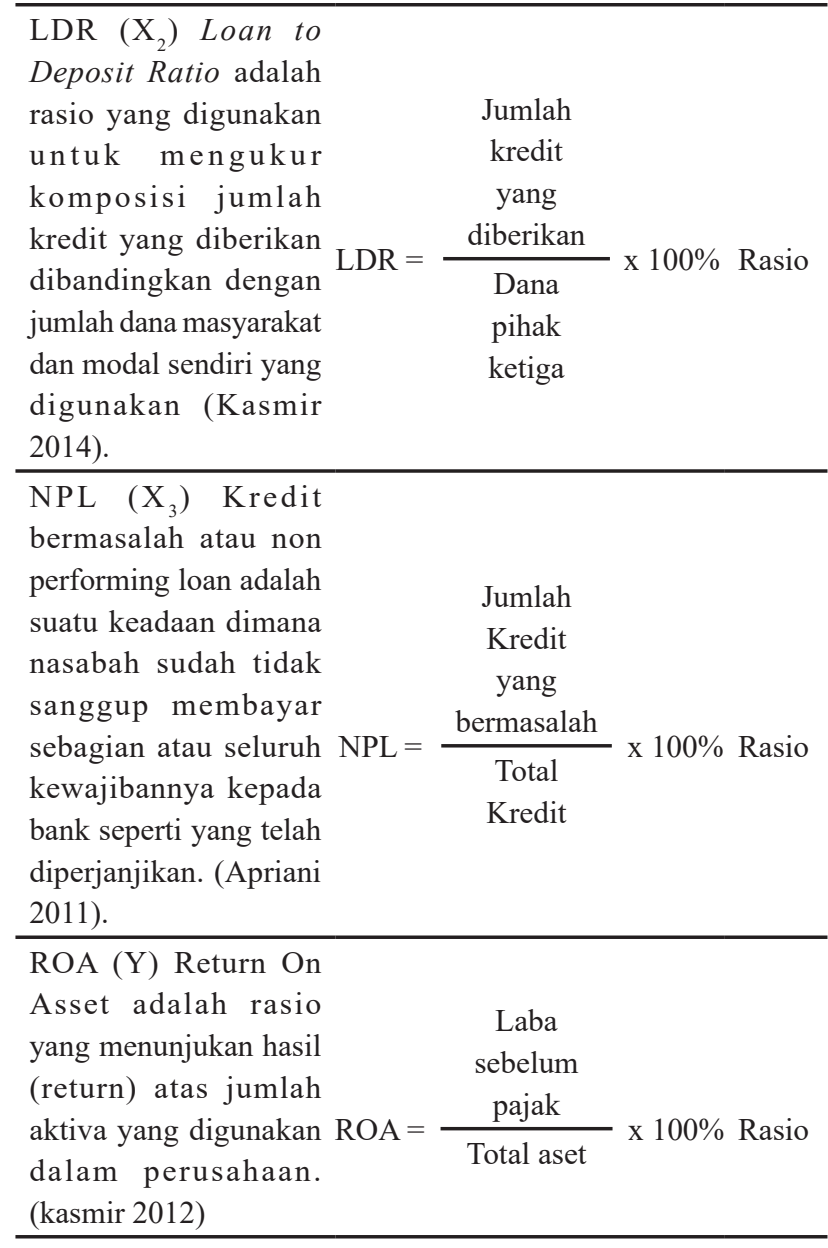

Populasi dalam penelitian ini adalah perusahaan perbankan yang terdaftar di Bursa Efek Indonesia tahun 2011-2015. Teknik yang digunakan dalam penelitian ini adalah purposive sampling yang dan diperoleh 155 unit sampel dari 31 sampel perusahaan sektor perbankan selama tahun 2011-2015. Teknik analisis yang digunakan dalam penelitian ini adalah analisis statistik deskriptif dan regresi data panel dengan persamaan regresi data panel sebagai berikut :

$$
Y=\alpha+\beta_{1} X_{1} 1 \text { it }+\beta_{2} X_{2} \text { it }+\beta_{3} X_{3} 3 i t+e
$$

$$
\begin{array}{ll}
\mathrm{Y} & =\text { ROA } \\
\alpha & =\text { Konstanta } \\
\beta_{1}, \beta_{2}, \beta_{3} & =\text { Koefisien Regresi masing masing variabel independen } \\
\mathrm{X}_{1 \mathrm{it}} & =\mathrm{CAR} \\
\mathrm{X}_{2 \mathrm{it}} & =\mathrm{LDR} \\
\mathrm{X}_{3 \mathrm{it}} & =\mathrm{NPL} \\
\mathrm{e} & =\text { Error term }
\end{array}
$$

\section{HASIL}

Hasil analisis deskriptif variabel operasional ditunjukkan pada Tabel 2.

Tabel 2. Hasil Uji Statistik Deskriptif

\begin{tabular}{lcccc}
\hline & CAR & LDR & NPL & ROA \\
\hline Mean & 0.1834 & 0.8295 & 0.0226 & 0.0163 \\
Maximum & 0.8749 & 1.4072 & 0.1228 & 0.0542 \\
Minimum & 0.0941 & 0.4346 & 0 & -0.0758 \\
Std. Dev. & 0.1025 & 0.1352 & 0.0176 & 0.0169 \\
Observ. & 155 & 155 & 155 & 155 \\
\hline
\end{tabular}

Berdasarkan data dari Tabel 2 menunjukkan bahwa tiga variabel operasional yang memiliki nilai mean lebih besar dibandingkan standar deviasi yaitu CAR, LDR dan NPL yang dapat diartikan bahwa data tersebut tidak menyebar dan tidak bervariasi, sedangkan pada variabel ROA terdapat nilai mean yang lebih kecil dari standar deviasi yang berarti bahwa data tersebut menyebar dan bervariasi.

\section{PEMBAHASAN}

Nilai rata-rata CAR perusahaan sektor perbankan yang terdaftar di Bursa Efek Indonesia selama tahun 2011-2015 adalah sebesar 0,1834 dikategorikan baik karena di atas minimum $8 \%$ yang ditetapkan. Nilai rata-rata dari CAR sebesar 0,1834 dengan standar deviasi sebesar 0,1025253 atau $10,25 \%$ yang artinya memiliki tingkat penyimpangan yang kecil serta data relatif homogen. Nilai maksimum dari CAR yaitu sebesar 0,8749 atau $87,49 \%$ sangat baik jauh ketentuan minimal yang dimiliki oleh Bank Nationalnobu Tbk 
pada tahun 2013. Berdasarkan Annual Report 2013 Bank Nationalnobu Tbk (NOBU). Nilai minimum dari CAR yaitu sebesar 0,0941 atau 9,41\% yang dimiliki oleh Bank J Trust Indonesia Tbk (BCIC) tahun 2011 sedikit tiis di atas ketentuan namun masih tergolong baik.

LDR merupakan rasio yang mengukur penyaluran dana dari peminjaman menggunakan dana yang dihimpun dari pembiayaan. Berdasarkan Tabel 2. LDR memiliki nilai rata-rata sebesar 0,8295 tergolong baik dalam fungsi intermediasi maupun tingkat likuiditas diantara $78-100 \%$. Sedangkan standar deviasi sebesar 0,1352 atau $13,52 \%$ yang lebih kecil dari mean itu artinya memiliki tingkat penyimpangan yang kecil serta relatif. Nilai maksimum LDR sebesar 1,4072 atau 140,72\% yang dimiliki oleh Bank Woori Saudara Indonesia 1906 Tbk pada tahun 2015 menunjukkan likuiditas yang menghawatirkan atas dana pihak ketiga karena di atas $100 \%$. Nilai minimum LDR sebesar 0,4346 atau 43,46\% yang dimiliki oleh Bank Nationalnobu Tbk pada tahun 2015 hal ini menunjukkan tingkat intermediasi yang rendah dari bank dalam memberikan pinjaman ke masyarakat.

NPL memiliki nilai rata-rata sebesar 0,0226 artinya mash di batas bawah $5 \%$ yang telah ditetakan. Nilai ratarata tersebut memiliki risiko pembiayaan yang tinggi. Standar deviasi yang lebih kecil dari nilai rata-rata yaitu sebesar 0,0176 itu artinya bahwa nilai standar deviasi tersebut kurang dari nilai rata-rata dan memiliki tingkat penyimpangan yang kecil serta relatif homogen karena semakin kecil tingkat penyimpanganya maka semakin kecil pula variasi datanya. Nilai maksimum dari NPL adalah 0,1228 atau $12,28 \%$ yang dimiliki oleh Bank J Trust Indonesia Tbk pada tahun 2015 yang artinya terdaat kredit bermasalah yg tinggi hingga melewati batas aman. Nilai minimum dari NPL adalah 0,0000 atau $0 \%$ dimiliki oleh Bank Nationalnobu Tbk (BCAS) sepanjang tahun 2011 hingga 2015 di mana syarat yang ketat dalam memberikan pinjaman mmbuat nilai NPL nya aman.

Rata-rata ROA sebesar 0,0163 sehingga secara rata-rata keseluruhan bank umum memperoleh profitabilitas yang baik dan tidak merugi dan tergolong baik setidaknya rata-rata yang ada tidak menunjukkan nilai negatif. Standar deviasi sebesar 0,0169 atau $1,70 \%$ itu artinya ROA memiliki standar deviasi yang lebih besar sehingga nilai rata-rata ROA memiliki tingkat penyimpangan yang besar dan data relatif heterogen berdasarkan rata-rata tersebut, terdapat tujuh bank umum yang memiliki ROA diatas rata-rata selama lima tahun berturut-turut. Nilai maksimum ROA dimiliki oleh Bank Mestika Dharma Tbk pada tahun 2013 sebesar 0,0542 atau 5,42\%. Nilai minimum dimiliki oleh Bank J Trust Indonesia Tbk pada tahun 2013 sebesar -0,0758 atau $-7,58 \%$ buruk karena mengalami kerugian.

Berdasarkan regresi data panel dengan metode random effect, Pengujian untuk menentukan model yang cocok antara common effect atau fixed effect sehingga sesuai untuk penelitian yang dilakukan dengan uji chow dengan kriteria pengambilan keputusan yaitu: (a) Probability (p-value) Cross-section $F<0,05$ atau Probability (p-value) Cross-section Chi-square $<0,05$ maka $\mathrm{H}_{\mathrm{o}}$ ditolak atau dapat dikatakan bahwa model yang lebih baik adalah Fixed Effect. (b) Probability (p-value) Cross-section $F>0,05$ atau Probability

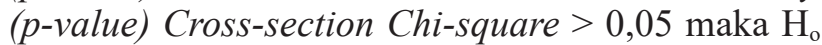
diterima atau dapat dikatakan bahwa model yang yang lebih baik adalah Common Effect.

Tabel 3. Hasil Uji Chow

Redundant Fixed Effects Tests

Equation: Untitled

Test cross-section fixed effects

\begin{tabular}{lrrl}
\hline Effects Test & \multicolumn{1}{c}{ Statistic } & d.f. & Prob. \\
\hline Cross-section F & 9.373822 & $(30,121)$ & 0.0000 \\
Cross-section Chi-square & 186.185282 & 30 & 0.0000 \\
\hline
\end{tabular}

Sumber: Hasil output Eviews versi 9

Hasil Uji Chow, menunjukkan probability ( $p$-value) cross section $F$ sebesar $0.0000<0,05$ dengan taraf signifikansi sebesar 5\%. Dapat diputuskan bahwa model fixed effect lebih baik daripada model common effect. Setelah Uji Chow selesai dilaksanakan, maka dilanjutkan dengan Uji Hausman.

Pengujian ini dilakukan untuk menentukan model yang cocok antara fixed effect atau random effect sehingga sesuai untuk penelitian yang dilakukan.

Tabel 4. Hasil Uji Hausman

Correlated Random Effects - Hausman Test

Equation: Untitled

Test cross-section random effects

\begin{tabular}{lrrr}
\hline Test Summary & Chi-Sq. Statistic & Chi-Sq. d.f. & Prob. \\
\hline Cross-section random & 4.432317 & 3 & 0.2184 \\
\hline
\end{tabular}

Sumber: Hasil output Eviews versi 9

Tabel 5. Hasil Pengujian Signifikansi Random Effect

\begin{tabular}{|c|c|c|c|c|}
\hline Variable & Coefficient & Std. Error & t-Statistic & Prob. \\
\hline $\mathrm{C}$ & 2.309174 & 0.788729 & 2.927713 & 0.0039 \\
\hline CAR & 13.82708 & 6.775727 & 2.040678 & 0.0430 \\
\hline LDR & -37.60208 & 49.86710 & -0.754046 & 0.4520 \\
\hline NPL & -0.465841 & 0.061388 & -7.588474 & 0.0000 \\
\hline & \multicolumn{2}{|c|}{ Effects Specification } & S.D. & Rho \\
\hline \multicolumn{3}{|c|}{ Cross-section random } & 1.149779 & 0.6358 \\
\hline \multicolumn{3}{|c|}{ Idiosyncratic random } & 0.870287 & 0.3642 \\
\hline \multicolumn{5}{|c|}{ Weighted Statistics } \\
\hline$R$-squared & 0.294122 & \multicolumn{2}{|c|}{ Mean dependent var } & 0.522754 \\
\hline $\begin{array}{l}\text { Adjusted } \\
R \text {-squared }\end{array}$ & 0.280098 & \multicolumn{2}{|c|}{ S.D. dependent var } & 1.030566 \\
\hline $\begin{array}{l}\text { S.E. of } \\
\text { regression }\end{array}$ & 0.874404 & \multicolumn{2}{|c|}{ Sum squared resid } & 115.4520 \\
\hline
\end{tabular}




\begin{tabular}{lccc}
\hline $\begin{array}{l}\text { F-statistic } \\
\text { Prob(F- } \\
\text { statistic) }\end{array}$ & 20.97270 & Durbin-Watson stat & 1.711481 \\
\hline \multicolumn{4}{c}{0.000000} \\
\hline Unweighted Statistics \\
\hline $\begin{array}{l}\text { R-squared } \\
\begin{array}{l}\text { Sum squared } \\
\text { resid }\end{array}\end{array}$ & 0.283017 & Mean dependent var & 1.630387 \\
\hline
\end{tabular}

Hasil Uji Hausman, menunjukkan p-value crosssection random sebesar $0.2184>0,05$ dengan taraf signifikansi sebesar 5\%. Berdasarkan data tersebut, model regresi data panel yang digunakan adalah Model Random Effect lebih baik daripada Model fixed Effect.

Adjusted R-Squared model penelitian adalah sebesar 0,280098 atau $28 \%$, dan signifikan, maka CAR, LDR dan NPL dapat menjelaskan atau mempengaruhi yaitu profitabilitas bank umum di Indonesia periode 2011-2015 yang diproksikan dengan ROA sebesar $28 \%$, sedangkan sisanya yaitu $72 \%$ dipengaruhi oleh variabel lain.

Capital adequacy ratio secara parsial berpengaruh signifikan terhadap profitabilitas. Loan deposit ratio secara parsial tidak berpengaruh terhadap profitabilitas. Berarti LDR yang tinggi tidak serta memberikan profitabilitas yang tinggi juga dikarenakan harus dilihat juga apakah total kredit yang diberikan terhadap dana pihak ketiga yang dihimpun berjalan dengan efektif dengan melihat NPL yang menggambarkan total kredit bermasalah terhadap total kredit yang diberikan. Hal ini didukung melihat di mana pada data terdapat 5 Bank yang memiliki LDR di bawah dari interval ketetapan Bank Indonesia yakni 78\% sepanjang tahun 2011 hingga 2016 (Kecuali Bank Nobu pada 2011) namun tetap memperoleh nilai positif pada profitabilitasnya. Non performing loan secara parsial berpengaruh signifikan terhadap profitabilitas.

\section{KESIMPULAN}

Capital Adequcy Ratio, Loan Deposit Ratio, Non Performing Loan, dan Return On Assets sektor perbankan yang terdaftar di Bursa Efek Indonesia selama tahun 2011-2015 dikategorikan baik, karena berada dalam batas yang ditetapkan Bank Indonesia.

Secara simultan CAR, LDR dan NPL berpengaruh signifikan terhadap profitabilitas perusahaan perbankan yang terdaftar pada Bursa Efek Indonesia. Sedangkan secara parsial, CAR berpengaruh positif signifikan terhadap profitabilitas perusahaan perbankan yang terdaftar pada Bursa Efek Indonesia, NPL berpengaruh negatif signifikan terhadap profitabilitas perusahaan perbankan yang terdaftar pada Bursa Efek Indonesia. Sedangkan LDR tidak berpengaruh terhadap profitabilitas bagi perusahaan perbankan yang terdaftar pada Bursa Efek Indonesia.

\section{DAFTAR PUSTAKA}

Adyani, Lyla Rahma. 2011. Analisis Faktor-Faktor Yang Mempengaruhi Profitabilitas. Jurnal Ekonomi dan Bisnis Universitas Diponegoro.

Agustiningrum, Riski. 2012. Analisis Pengaruh CAR, NPL, Dan LDR Terhadap Profitabilitas Pada Perusahaan Perbankan. Jurnal Akuntansi Universitas Udayana Vol. 2 No. 8

Hardiyanti. 2012. Pengaruh CAR, NPL Dan LDR Terhadap ROA Pada Bank Bumn Yang Go-Public Di Indonesia. Jurnal Akuntansi Universitas Hasanuddin Makassar

Kasmir. S.E., M.M. 2008. Bank dan Lembaga Keuangan Lainnya. Jakarta: PT. Raja Grafindo Persada.

Kasmir. 2012. Bank dan Lembaga Keuangan Lainnya. Depok: Rajagrafinda Persada.

Latumaerissa, Julius R. 2011. Bank dan Lembaga Keuangan Lainnya. Salemba Empat. Jakarta Selatan.

Latumaerissa, J.R., 2014. Manajemen Bank Umum. Jakarta: Mitra Wacana Media.

Mahmoeddin, A.S., 2010. Melacak Kredit Bermasalah, cetakan pertama. Penerbit: Pustaka Sinar Harapan, Jakarta.

Minning Durrotun Nikmah, A., 2012. Sistem Informasi Penjualan Online Pada Sugiarto Rattan Furniture Jepara (Doctoral dissertation, Universitas Muria Kudus).

Wardiah, M.L., 2013. Dasar-Dasar Perbankan. Bandung. CV Pustaka Setia.

Wibisono, Kunto. 2012. Pengaruh CAR, NPL, NIM, Dan LDR Pada Profitabilitas Bank Umum Swasta Nasional Di Indonesia. Jurnal Akuntansi UNTAN JEDA2 Vol 1 No. 